\title{
pommalina
}

(8)

\section{Braila: cidade no Danúbio}

Autor(es): $\quad$ Lascu, Nicolae, ed. lit.; China, Andreea Mirela

Publicado por: Imprensa da Universidade de Coimbra

URL

persistente:

URI:http://hdl.handle.net/10316.2/39320

DOI:

DOl:http://dx.doi.org/10.14195/978-989-26-1025-2_5

Accessed : $\quad$ 26-Apr-2023 11:35:12

A navegação consulta e descarregamento dos títulos inseridos nas Bibliotecas Digitais UC Digitalis, UC Pombalina e UC Impactum, pressupõem a aceitação plena e sem reservas dos Termos e Condições de Uso destas Bibliotecas Digitais, disponíveis em https://digitalis.uc.pt/pt-pt/termos.

Conforme exposto nos referidos Termos e Condições de Uso, o descarregamento de títulos de acesso restrito requer uma licença válida de autorização devendo o utilizador aceder ao(s) documento(s) a partir de um endereço de IP da instituição detentora da supramencionada licença.

Ao utilizador é apenas permitido o descarregamento para uso pessoal, pelo que o emprego do(s) título(s) descarregado(s) para outro fim, designadamente comercial, carece de autorização do respetivo autor ou editor da obra.

Na medida em que todas as obras da UC Digitalis se encontram protegidas pelo Código do Direito de Autor e Direitos Conexos e demais legislação aplicável, toda a cópia, parcial ou total, deste documento, nos casos em que é legalmente admitida, deverá conter ou fazer-se acompanhar por este aviso. 


\section{BRAILA \\ CIDADE NO DANÚBIO}

NICOLAE LASCU (Coordenador)

ANDREEA MIRELA CHINA 


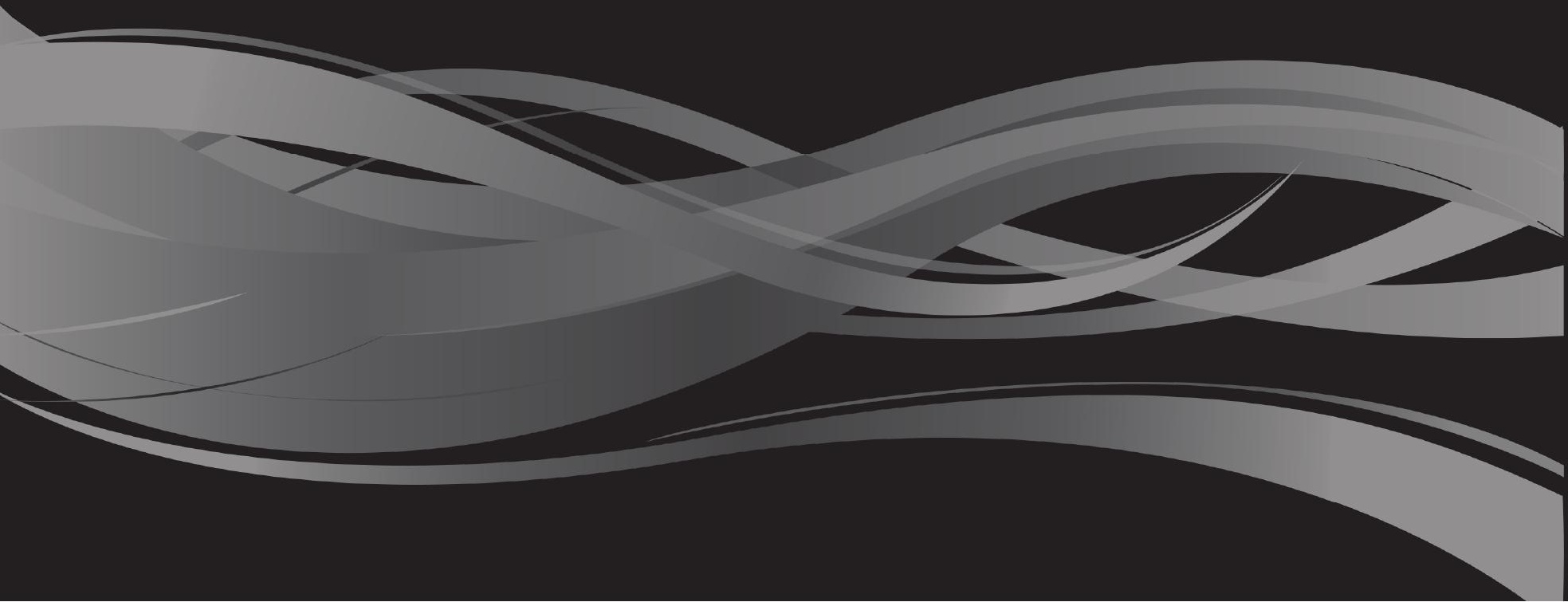


Braila, capital do distrito do mesmo nome, é hoje uma cidade com cerca de 240.000 habitantes. Importante cidade portuária do Danúbio situada no trecho final do rio antes de desaguar no Mar Negro, é também o último porto fluvial até onde as embarcações marítimas de médio calado conseguem subir. Como todas as grandes cidades portuárias, Braila já foi uma cidade multicultural. Nela viveram importantes comunidades gregas e judaicas, bem como de lipovanos e outros povos estrangeiros, conheceu uma vida cultural intensa, e deu ao país prestigiados representantes em domínios que vão das ciências naturais às artes.

Sobre a relação especial de Braila com o rio Danúbio podemos considerar, do ponto de vista do presente projeto, três níveis distintos de complexidade: o problema mais amplo que é o da unidade de paisagem, relativo ao vasto território do Danúbio na Roménia; a questão do sistema urbano Braila-Galati, territorialmente mais circunscrito; e a cidade propriamente dita. Considerada deste prisma, a reabilitação do centro histórico e da frente ribeirinha de Braila não pode ser vista separadamente do desenvolvimento potencial do território do Danúbio no seu conjunto, pois as respetivas histórias estão fortemente interligadas. A água e toda a paisagem fluvial - que há que considerar património, intimamente associado ao próprio património urbano de Braila - articulam-se com a parte mais valiosa da estrutura urbana através da frente ribeirinha, que aqui assume por inteiro o caráter de espaço público.

O Danúbio, segundo maior rio da Europa, com uma bacia de drenagem com mais de 800.000 $\mathrm{km}^{2}$, atravessa nove países e quatro capitais. O canal formado pelo Reno, Main e Danúbio liga o Mar do Norte ao Mar Negro. Isto faz do Danúbio um rio intrinsecamente europeu, conclusão que é reforçada pelas grandes orientações definidas em 2010 pela Comissão Europeia na sua Estratégia da União Europeia para o Rio Danúbio.

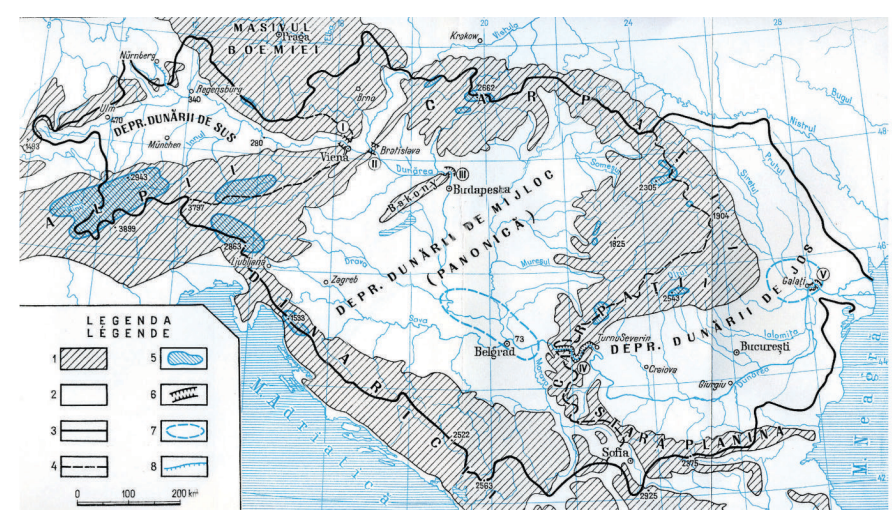

O Danúbio na Europa

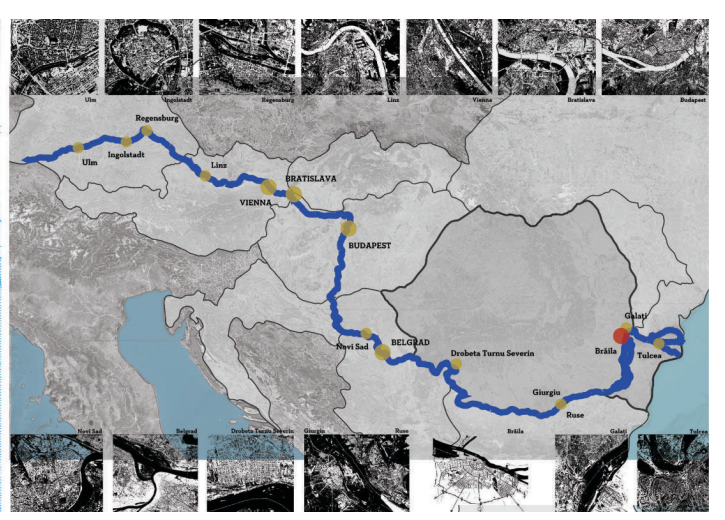

Bacia de drenagem do Danúbio

\section{A unidade de paisagem do território}

Um terço do rio corre em território romeno. Este trecho, chamado Baixo Danúbio, constitui, segundo a Convenção Europeia da Paisagem, uma unidade de paisagem. A unidade de paisagem 
define-se como sendo uma porção de território com caraterísticas comuns: tem de apresentar uma certa coerência, aquirida ao longo da sua evolução histórica, e tem também de ostentar a influência de fatores humanos, nomedamente por parte das comunidades que ali vivam. Por um lado, as unidades de paisagem são, em parte, moldadas pela geografia - no caso do Baixo Danúbio, pelas condições topográficas que influenciam a distribuição das áreas húmidas que ladeiam o rio.

Por outro lado, as unidades de paisagem são moldadas pelas importantes funções simultânea ou sequencialmente desempenhadas pelo espaço geográfico (no caso vertente, o Danúbio). De entre estas destacou-se o comércio, principal catalisador do rápido desenvolvimento, em meados do século XIX, de uma rede de cidades portuárias ligadas entre si. Mais tarde, estas tornaram-se nódulos que iriam viabilizar a articulação de complexas relações regionais, com um papel especialmente importante no desenvolvimento de toda uma rede de povoações e do sistema de transportes (quer dizer, das redes viária e ferroviária). O rio pode, assim, ser considerado um sistema natural complexo, em que as componentes natural e cultural funcionam de maneira concertada.

Depois de atravessar os Cárpatos a caminho do Mar Negro, o Danúbio dá origem a uma configuração muito própria. Ao longo do seu curso, antes de atingir o delta, a margem direita (do lado búlgaro) é mais elevada, sendo a esquerda constituída principalmente pela Planície Romena, terreno plano e de baixa altitude. A complexa configuração geomorfológica do território atravessado pelo Danúbio dá azo à existência de vastas áreas húmidas, que dependem do rio e são por este criadas. O rio e as áreas húmidas criam um todo orgânico, uma paisagem contínua mas diversificada e de largura variável.

O leito principal recebe inúmeros tipos de afluentes, canais, ribeiros, lagos, lagoas, pântanos, leitos de cheia, etc. Estas áreas aquáticas, invariavelmente resultantes da corrente, criam um todo orgânico, uma paisagem que é contínua e diversa, com uma largura que vai até aos $60 \mathrm{~km}$. Por fim, o trecho final do rio, navegável por navios de mar e situado principalmente na região do chamado Delta do Danúbio, é, verdadeiramente, o reino das águas.

A dinâmica das intervenções a que o território do Danúbio foi sujeito teve grande importância após a Segunda Guerra Mundial, altura em que, através de diversas obras hidráulicas, algumas áreas consideráveis - incluindo o Grande Paúl de Braila (por isso mesmo designado Ilha Grande de Braila) - foram reconvertidas para fins agrícolas. Este facto veio alterar especialmente o equilíbrio hidrológico e, de um modo mais geral, o equilíbrio ecológico, numa grande parte do percurso.

Ao longo dos tempos o Danúbio desempenhou diversas funções de vulto, que foram impondo condicionalismos não só às redes de comunicação de terra mas também à estrutura urbana das localidades: funções como a de fronteira natural entre Estados, de facilitador do comércio, e ainda - dadas as possibilidades de transporte fluvial - de gerador de infraestruturas industriais na proximidade das cidades já existentes. 


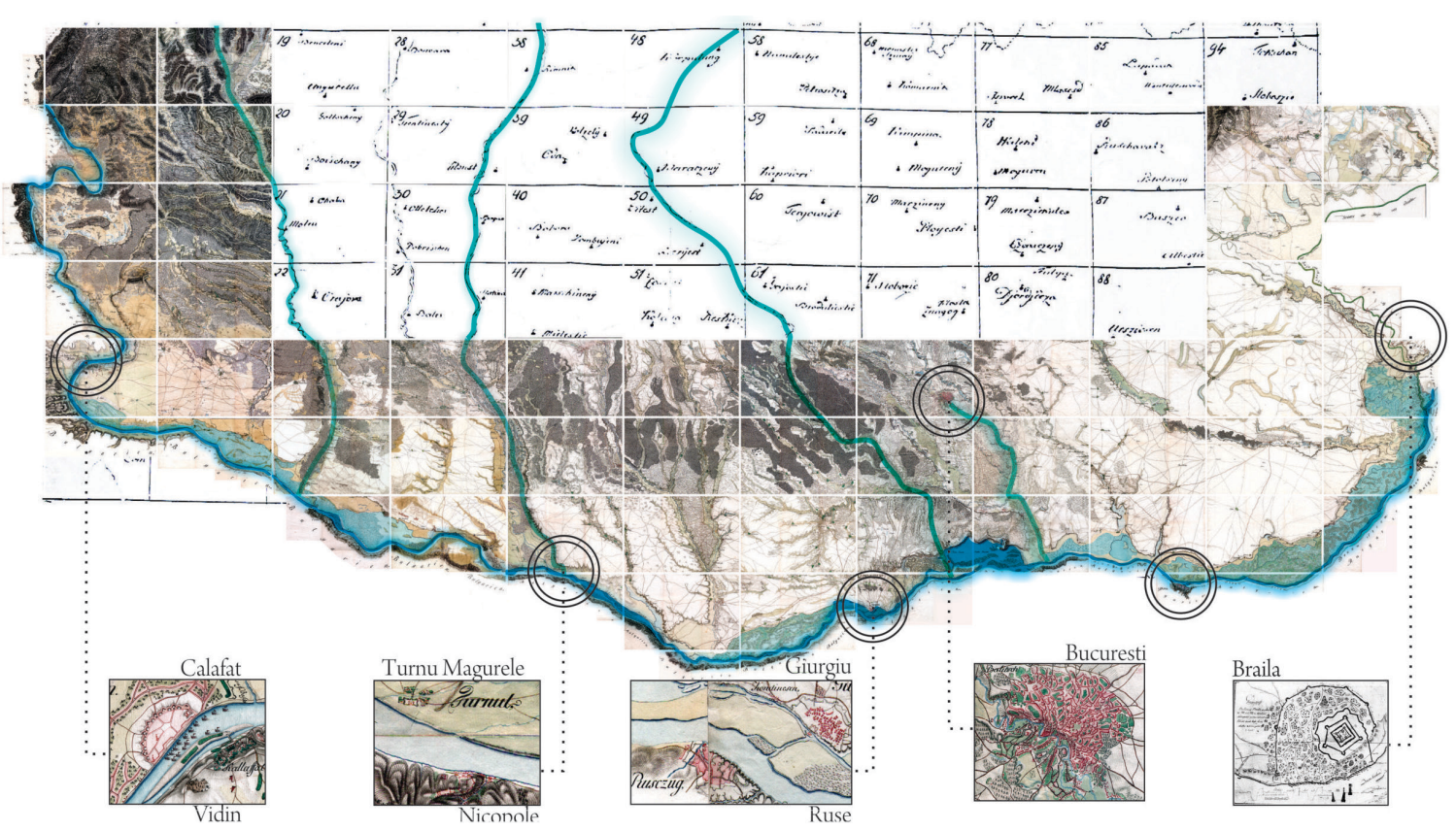

Mapa Militar da Valáquia, de Specht - 1789

A função mais antiga, e que ainda hoje perdura, é a de fronteira natural. Antes de tudo, o Danúbio foi um limes romano. A época romana e, a seguir, a bizantina (entre o século I A.C. e o século VI D.C.) fixaram as fronteiras dos impérios situados junto ao Danúbio, que assim passou a fazer parte dos respetivos sistemas defensivos.

Devido à sua extensão, o limes romano do Danúbio foi a mais importante fronteira fluvial criada pelos Romanos. Durante a época bizantina, do século VII ao século XIII, o rio desempenhou um papel menos importante tanto do ponto de vista militar como do ponto de vista económico, nomeadamente se comparado com a relevância económica e comercial então assumida pelo Mar Negro. Desse modo, nesse período de acentuada instabilidade política o limes romano deixou de existir em toda esta região. Só em meados do século XIV, com a formação dos Estados romenos (Tara Romaneasca e Moldávia), se regressou a um clima político de maior estabilidade, com o decorrente aumento da segurança para o comércio feito ao longo da região situada entre as montanhas e o Danúbio.

Na sua expansão, o Império Otomano alcançou o Danúbio por volta dos finais do século XIV, o que levou a que então o rio se tornasse, a norte, uma fronteira estável para o poderoso império em ascensão. Com a tomada dos fortes de Giurgiu e Turnu entre os anos de 1417 e 1420, e também de Braila na primeira metade do século seguinte (1541) - tudo cidades portuárias da margem esquerda -, os Otomanos asseguraram o controlo sobre o Baixo e o Médio Danúbio. Ao longo do século XVI a função militar do rio foi, aos poucos, sendo complementada pela função comercial, que viria a crescer exponencialmente durante os séculos seguintes. Esta nova função levou ao reforço dos laços entre as duas margens e à criação de cidades gémeas situadas frente a frente numa e noutra margem, com 
o rio a servir de via de passagem (casos de Turnu Severin - Kladovo, Calafat - Vidin, Turnu Magurele - Nicopole, Zimnicea - Svishtov, Giurgiu - Ruse, Oltenita - Turtucaia). As vias de comércio terrestres conduziam aos pontos de atravessamento do Danúbio e às cidades portuárias aí localizadas: as rotas comerciais iam desde Braila e Chilia até Targoviste, e a partir de Oltenia, Giurgiu, Zimnicea, Turnu, Calafat e Turnu Severin chegava-se até Brasov através da passagem de Rucar-Bran. Bucareste, a capital, juntamente com a cidade de Craiova, eram importantes encruzilhadas nestas rotas de comércio.

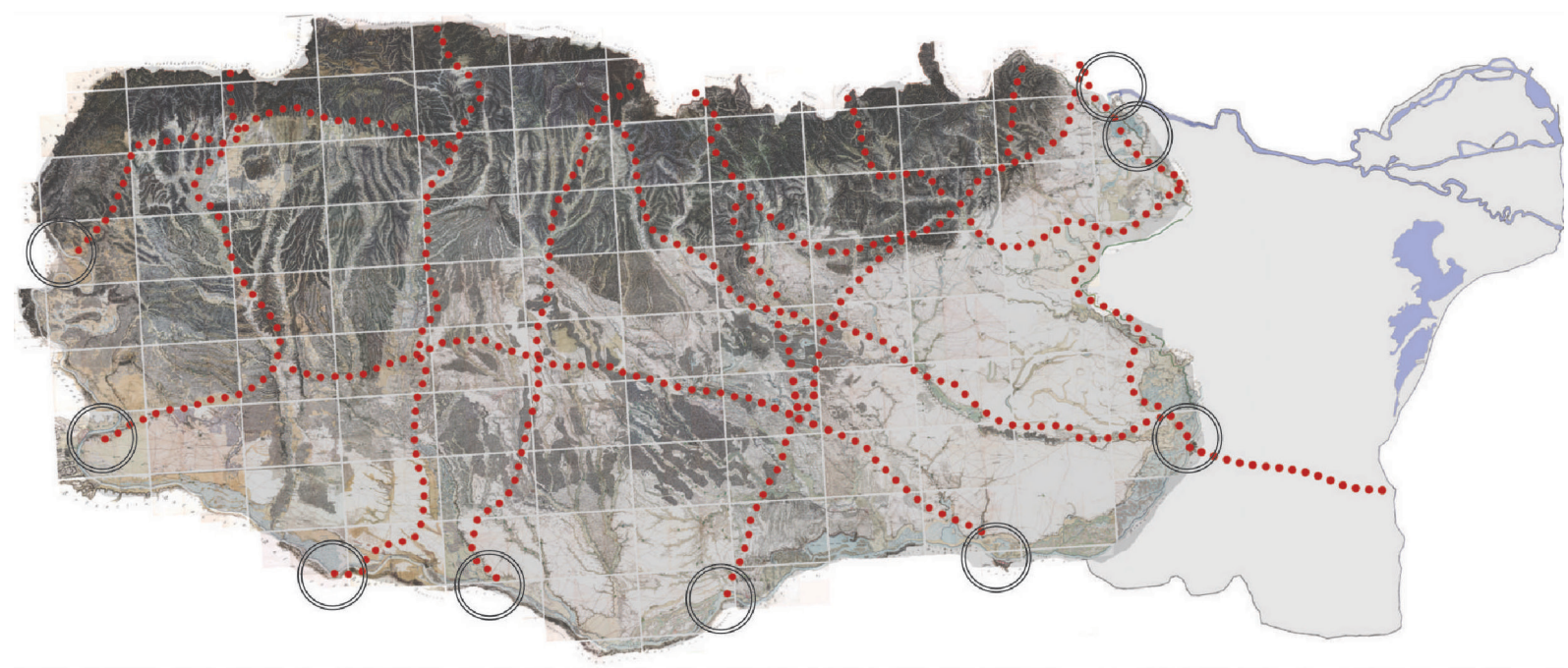

1800 - Rede de estradas e localidades da Valáquia

Para o segmento valáquio do Danúbio a era moderna tem início em 1829 com o Tratado de Paz de Adrianópolis. Este assinalou o fim do monopólio otomano, inclusivamente no respeitante ao rio, garantindo a liberdade de comércio e a reintegração, na Valáquia, dos portos de Turnu, Giurgiu e Braila, situadas na margem esquerda. A partir do momento em que as condições de comércio se alteraram, deixando este de estar voltado em exclusivo para o Império Otomano, o transporte no Danúbio tornou-se um factor económico de importância primordial. Deu-se, assim, uma reorientação não apenas no que se refere à travessia entre as duas margens - que sem dúvida esteve na origem das localidades "geminadas" -, mas também no que diz respeito ao transporte ao longo do rio. Na margem pertencente aos Principados Romenos iniciaram-se em 1832 iniciativas de desenvolvimento urbano com uma dimensão inaudita nestas paragens.

Data de então o desenvolvimento urbano devidamente planeado de 10 cidades portuárias: Braila, Giurgiu, Turnu Severin, Turnu Magurele, Zimnicea, Galati, Oltenita, Corabia, Calafat e Bechet. Alguns destes empreendimentos corresponderam a uma reestruturação significativa de localidades já existentes, enquanto noutros casos se tratou de projetos de desenvolvimento citadino inteiramente novos. No seu conjunto, estes portos de variável importância económica e administrativa vieram renovar por completo o sistema urbano da região danubiana, dando origem a uma nova estrutura territorial no sul do país. 


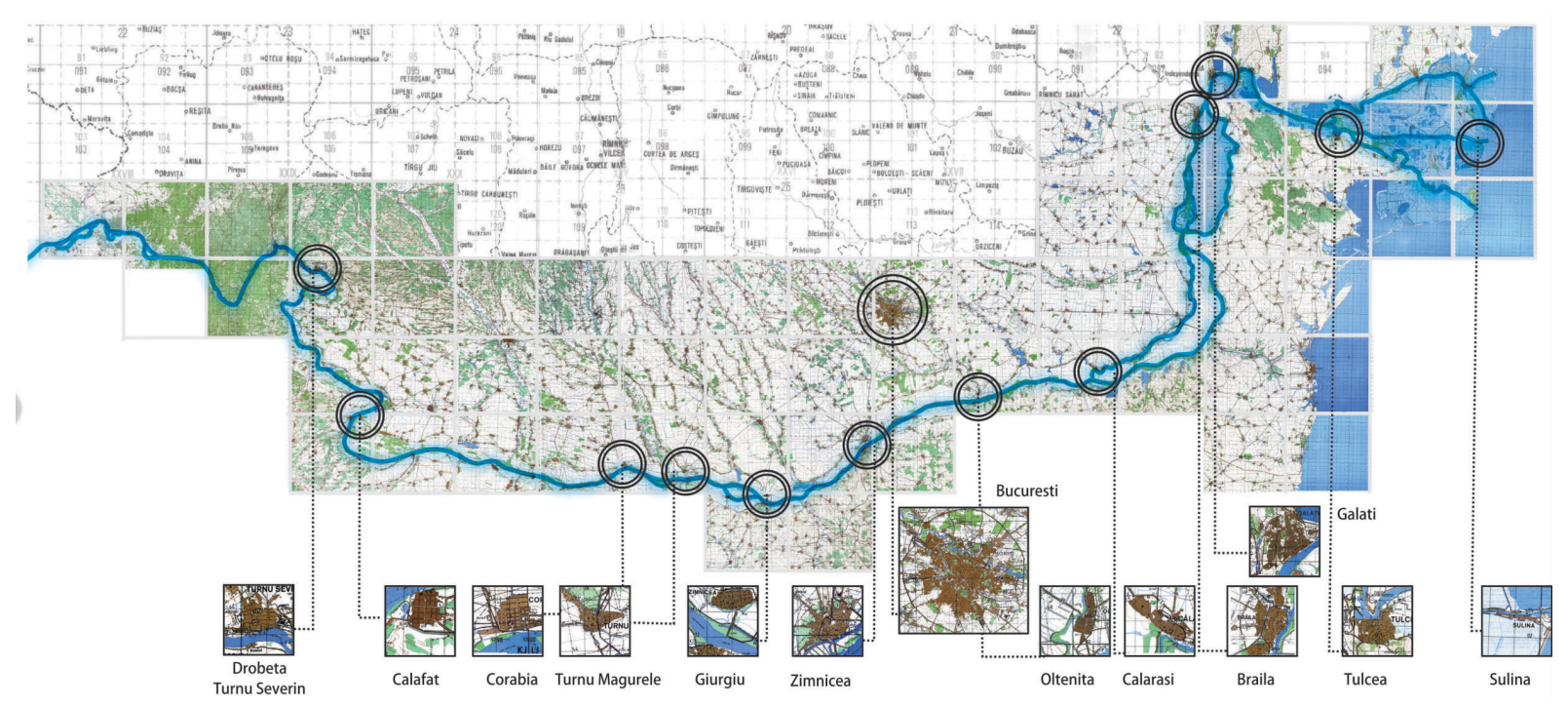

1975 - Mapa militar. O Rio Danúbio na Roménia, com as suas cidades portuárias

A partir de meados do século XIX as intervenções relativas às atividades portuárias foram acompanhadas, em alguns casos, de complexos industriais - estaleiros, mas também fábricas cuja atividade principal era a transformação dos diferentes tipos de mercadorias que para ali eram transportados, quer por via marítima, quer por via terrestre. Após a Segunda Guerra Mundial teve início um gigantesco projeto traduzido na construção, ao longo do rio, de diversas infraestruturas industriais, desde a metalomecânica (Galati, Calarai, Turnu Severin) ao setor químico (Turnu Magurele), passando pela produção de papel (Braila), etc. Outros grandes projetos que vieram mudar a paisagem do Danúbio foram o complexo hidroelétrico das Portas de Ferro, na fronteira com a Jugoslávia, e o canal do Danúbio-Mar Negro, em Dobrogea.

\section{Parte integrante do sistema urbano Braila-Galati}

Uma parte considerável da estrutura das paisagens terrestre e aquática do Danúbio é constituída pelos importantes portos de Braila e Galati, duas cidades da margem esquerda separadas por uma distância de 20 km. Em Dobrogea, próximo de Braila, num antigo canal do Danúbio, fica, na margem direita, um terceiro porto, o de Macin, de importância bem menor. Os três portos têm como traço comum o situarem-se no extremo do trecho navegável por embarcações marítimas, o que quer dizer que a função que lhes é comum advém da sua ligação ao mar. Acresce que a sua relação com a água que os envolve se carateriza por uma grande espetacularidade: a chegada dos rios Siret e Prut ao Danúbio - o primeiro entre Braila e Galati, o segundo a jusante desta última cidade -, a presença do lago Brates e do Paúl de Braila, e ainda a inflexão do curso do Danúbio e a proximidade do delta, tornam a zona uma das paisagens aquáticas mais ricas de todo o rio Danúbio. 
O desenvolvimento económico e urbano que foi ocorrendo paralela e simultaneamente - e que se encontra patente não só no casco medieval mas também, sucessivamente, na moderna infraestrutura portuária e no surgimento e reforço de instalações industriais a seguir à Segunda Guerra Mundial conduziu a uma colaboração estreita entre as cidades mas também a uma certa competição. A investigação hoje em curso visa determinar a viabilidade de um importante macrossistema urbano Braila-Galati dotado de alcance nacional (e que incorpore as cidades portuárias de Macin e Isaccea e eventualmente também, por arrastamento, Tulcea). O estudo prevê que a zona venha a ser um nódulo de comunicações para toda a Região de Desenvolvimento do Sudeste da Roménia.
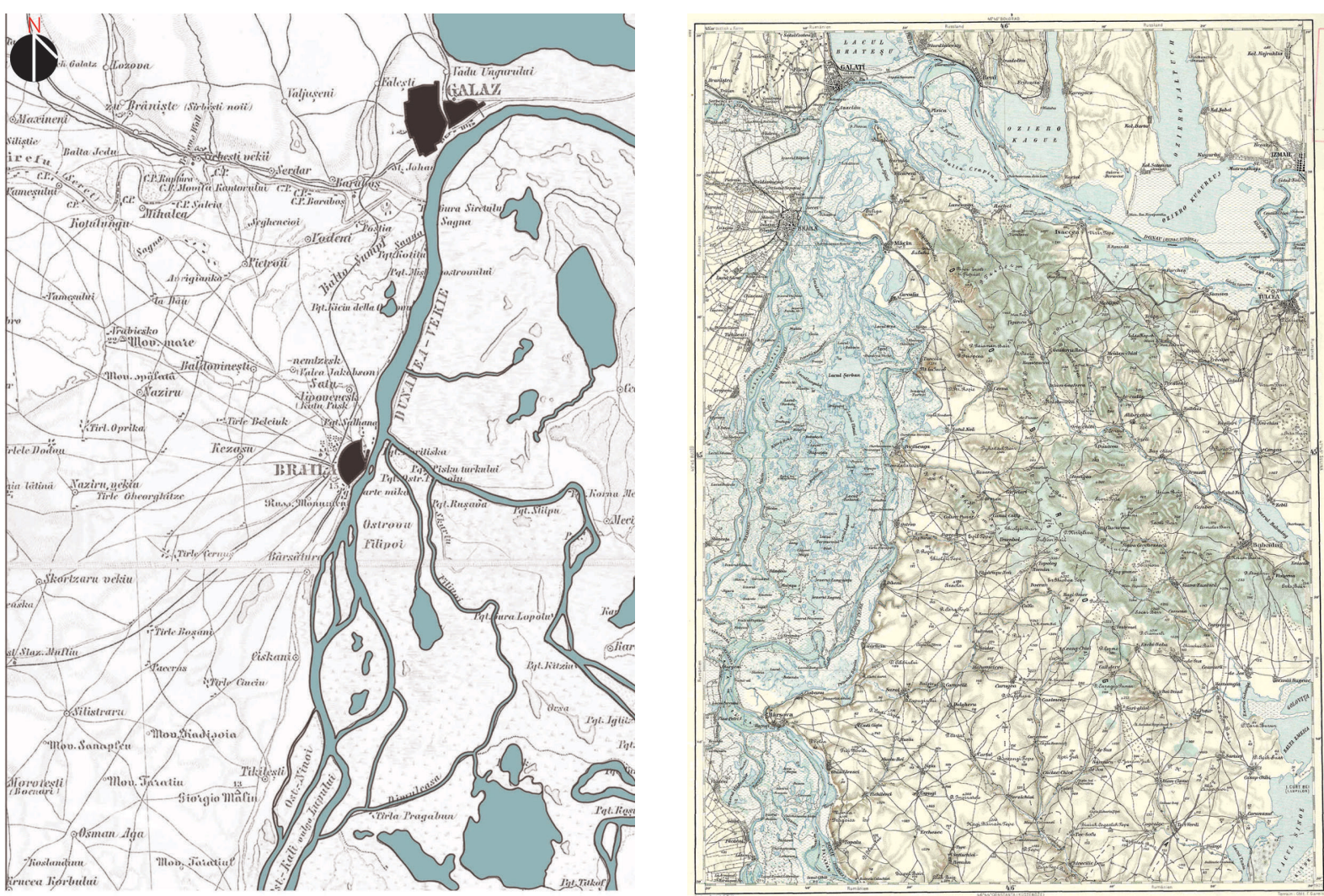

Evolução da paisagem fluvial relativa a Braila e Galati, 1867-1901

O projeto em causa propõe uma relação de maior complementaridade entre as duas grandes cidades, Braila e Galati, a partilha de infraestruturas (como sejam um aeroporto comum ou um nó intermodal localizado em Vladeni) e ligações mais rápidas com Dobrogea (nomeadamente através da construção de uma ponte sobre o Danúbio). Segundo o projeto, o valor excecional da paisagem natural, especialmente no que toca à relação complexa e multifacetada com a água e as áreas húmidas atrás referidas, poderá conduzir ao futuro desenvolvimento de um sistema urbano Braila-Galati que tenha na proteção das paisagens terrestre e fluvial um dos seus pilares fundamentais. 

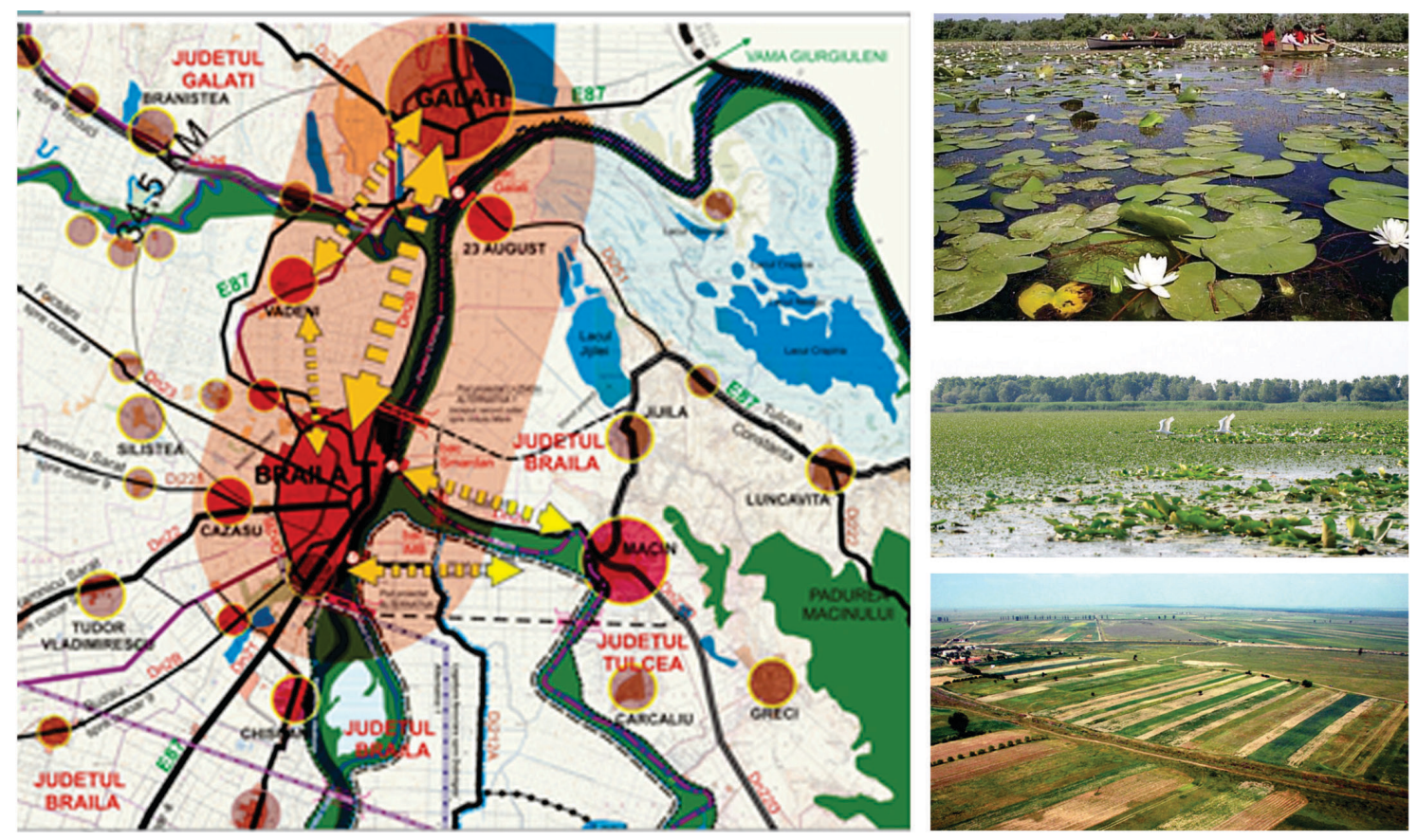

O sistema urbano Braila-Galati e o respetivo ecossistema

\section{Braila - cidade portuária}

Edificada em dois socalcos contíguos, Braila apresenta, de facto, um desnível. As zonas inferiores situam-se cerca de 3 a 4 metros acima do Danúbio, sendo aí que se localiza o porto e as infraestruturas com ele relacionadas. O socalco superior, sobre o qual a maior parte da cidade está construída, eleva-se entre 12 a 25 metros acima do rio, devido a uma vertente íngreme que, em parte, funciona como área de passeio na direção do Paúl de Braila.

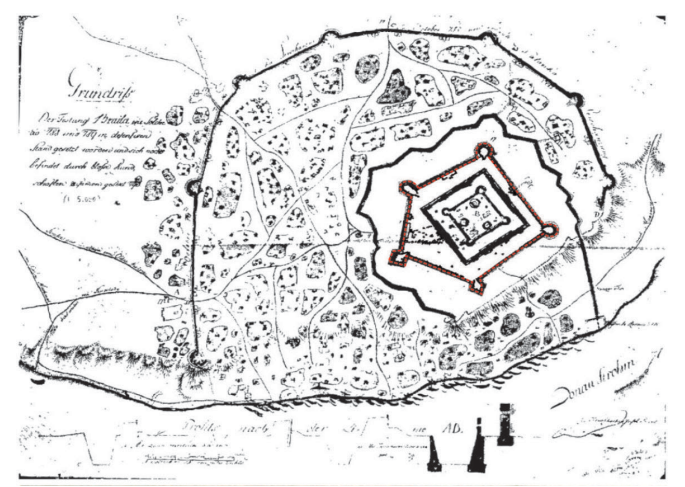

O primeiro mapa de Braila - fortaleza turca, 1789

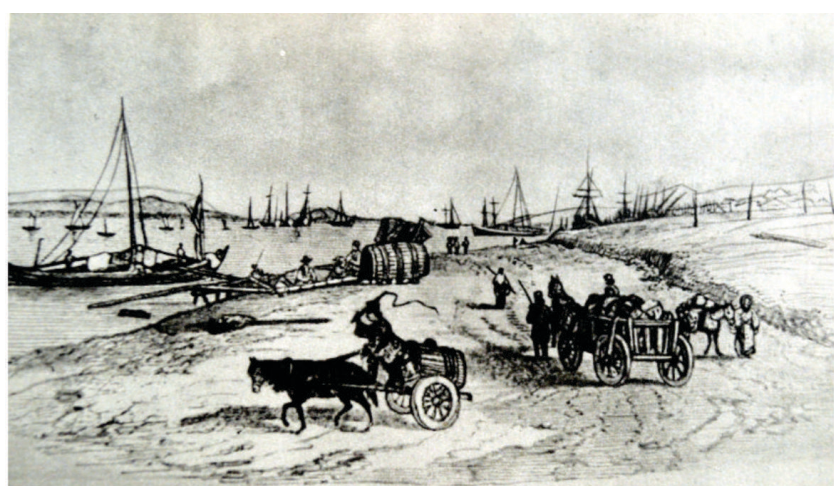

Vista sobre o porto - 1800 
As primeiras referências históricas a Braila surgem em documentos de 1368, período após o qual a cidade rapidamente se transformaria no porto mais importante da Munténia/ Valáquia. Em 1540 foi conquistada pelos Otomanos, que a incorporaram no sistema administrativo e defensivo turco. Fator determinante na evolução da urbe foi a construção pelos Otomanos, no século XVIII, de um sistema defensivo constituído por cinco grandes muralhas concêntricas. Em 1828 Braila voltou para as mãos da Valáquia, facto que inaugura a sua história moderna. O primeiro grande plano concebido para a cidade é de 1834 e deve-se a Rudolf von Boroczyn. A ideia principal do plano de Boroczyn consistiu em regularizar o desenho da muralha exterior, que circundava o povoamento setecentista, acrescentando um anel periférico em que abundavam os espaços verdes. O resultado foi uma moderna avenida, porventura a primeira dos Principados Romenos. Deste modo, o padrão geral assemelha-se, hoje, a um vasto semicírculo abrindo-se para o Danúbio, que aqui se apresenta largo. O plano previa ainda a criação do Jardim Público e da praça central (de forma quadrada), o embelezamento da zona das docas, e ainda a demolição da cidadela otomana e o loteamento dos terrenos assim libertados. Corrigiu-se a orientação das ruas antigas e outras ruas foram abertas, conferindo-se à cidade um aspeto quase geométrico, ao mesmo tempo que esta se expandia para lá do fosso da muralha antiga.

O núcleo do porto moderno fixou-se na zona inferior da cidade. O plano foi criado graças ao prolongamento parcial de uma estrutura mais antiga e bastante difusa. Os efeitos desta medida, que acabou por garantir a preservação de alguns traços, ainda podem ser observados, principalmente na parte situada a sudeste, junto ao Danúbio. A estes passos iniciais sobrepor-se-iam as ações de modernização, as quais vieram definir todo o conjunto da estrutura urbana, imprimindo-Ihe a forma particular que hoje ostenta. Associado ao crescimento demográfico, o paulatino mas espetacular crescimento económico de Braila ao longo do século XIX deu origem a sucessivas expansões da cidade, concretamente em 1855 e 1870. Manteve-se, no entanto,

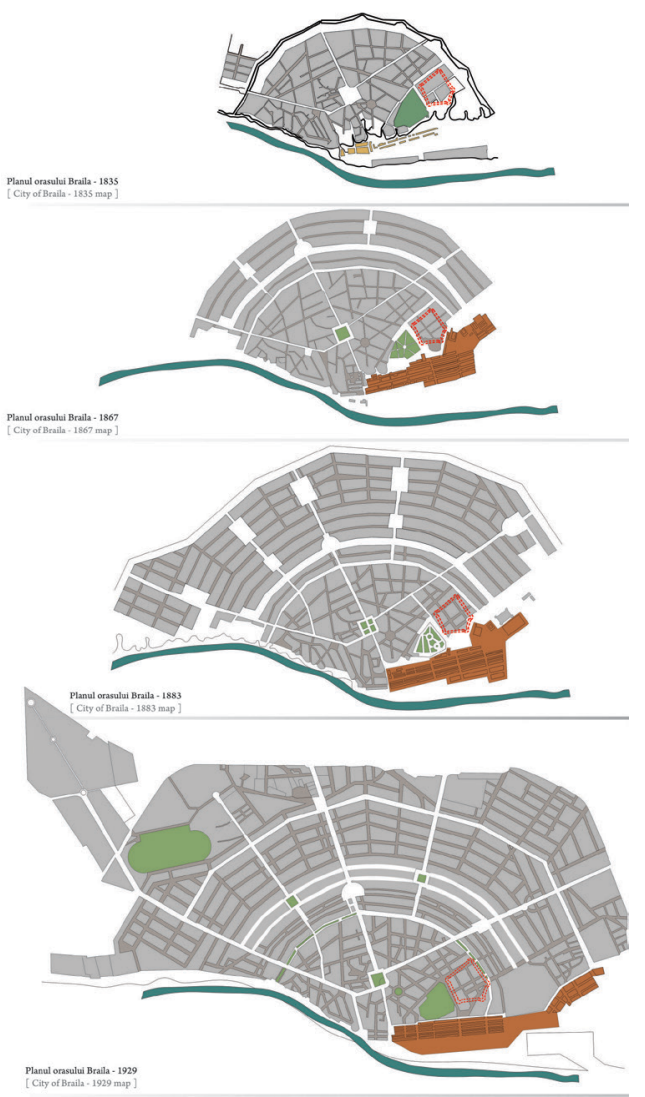

Evolução da cidade (com base em mapas antigos) de 1835 a 2012 
a ideia do semicírculo abrindo-se ao Danúbio, com uma estrutura radial e concêntrica, uniforme e bem organizada. A zona do porto foi delimitada no ano de 1879. Por outro lado, entre 1866 e 1891 toda essa área se foi modernizando, incluindo a parte das docas, os armazéns, e o imponente silo. Linhas ferroviárias paralelas servem toda a área de armazenamento, com algumas delas a acompanhar a margem do rio até à imensa fábrica de moagem Violatos (1898). Toda a frente ribeirinha, desde a Fábrica Violatos a sul até às docas situadas a norte, apresenta molhes e embarcadouros para navios de carga e de passageiros.

Todas estas intervenções ocorridas ao longo do século XIX acabaram por definir os traços daquilo que é, na atualidade, a parte mais antiga da cidade. Os casos de expansão posteriores a esse período e até à Segunda Guerra Mundial seguiram, em parte, esta bem organizada estrutura oitocentista, embora nem sempre respeitando a clareza e o rigor da geometria. A frente ribeirinha foi completamente ocupada pelas atividades portuárias e por edificações de tipo industrial ou áreas de armazenamento. No extremo sul, os estaleiros conheceram um desenvolvimento apreciável. A ligação de Braila com a água vê-se, assim, interrompida por dois importantes legados do seu passado industrial: os estaleiros e as docas. Entre as docas e os estaleiros fica o porto, que, com o seu traçado linear, ocupa a totalidade do socalco inferior. Mais tarde, as linhas do caminho de ferro prolongaram-se a sul até ao limite urbano do século XIX, o que implicou que a ligação de Braila com o Danúbio ficasse totalmente cortada, com exceção da Rua do Imperador Trajano e algumas pequenas artérias de pouco significado por onde é assegurado o acesso à zona portuária - ou seja, à gare fluvial, aos cais, aos armazéns e a outros espaços de armazenamento. A Rua do Imperador Trajano, que liga a praça central à frente ribeirinha, abre-se para um espaço amplo - a Praça do Porto, local de estacionamento para os numerosos veículos que aí afluem.

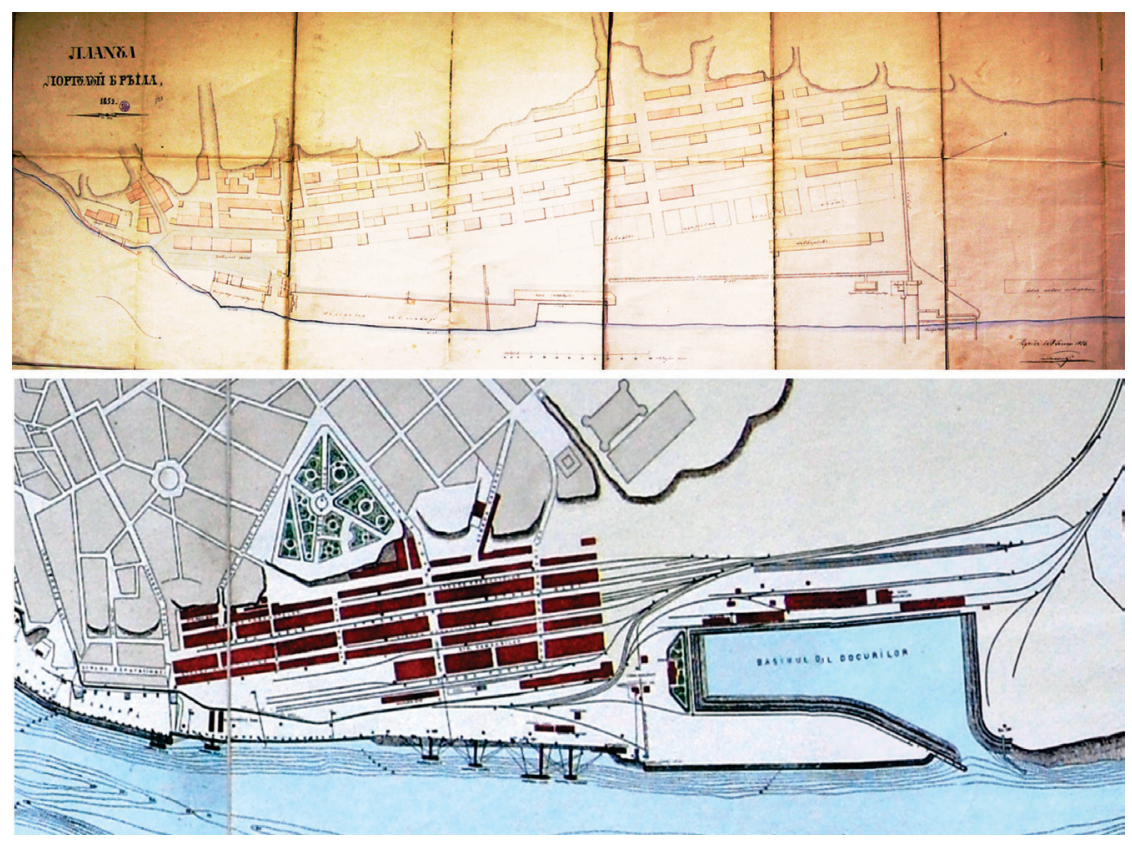

Mapas do porto, datados de 1852 e 1900 
Os processos de expansão da cidade que se seguiram à Segunda Guerra Mundial tiveram lugar ao longo da frente ribeirinha, tanto a norte como a sul, mas também a oeste, para o outro lado da linha férrea. Os sucessivos planos de desenvolvimento urbano empreendidos depois de 1950 procuraram harmonizar as estruturas do século XIX com os inevitáveis imperativos da modernização. Desses projetos, poucos foram os que tiveram em consideração a relação especial que Braila tem como a água. Um deles procede ao prolongamento da Avenida da Independência, a artéria semicircular que passa pelo meio da cidade, até ao limite da sua parte mais alta. Para sul, foi construído o edifício que funciona como sede da administração não só da cidade mas de todo o distrito. A reestruturação desta área permitiu uma ampla abertura em direção ao Danúbio, tendo ainda sido rasgadas vias paralelas em cotas diversas, acompanhando a frente ribeirinha até à Moagem Violatos. É esta, hoje em dia, a única ligação efetiva entre a cidade e o rio, não obstante tratar-se de uma solução que ignora outras relações possíveis entre a urbe histórica e a frente do rio.
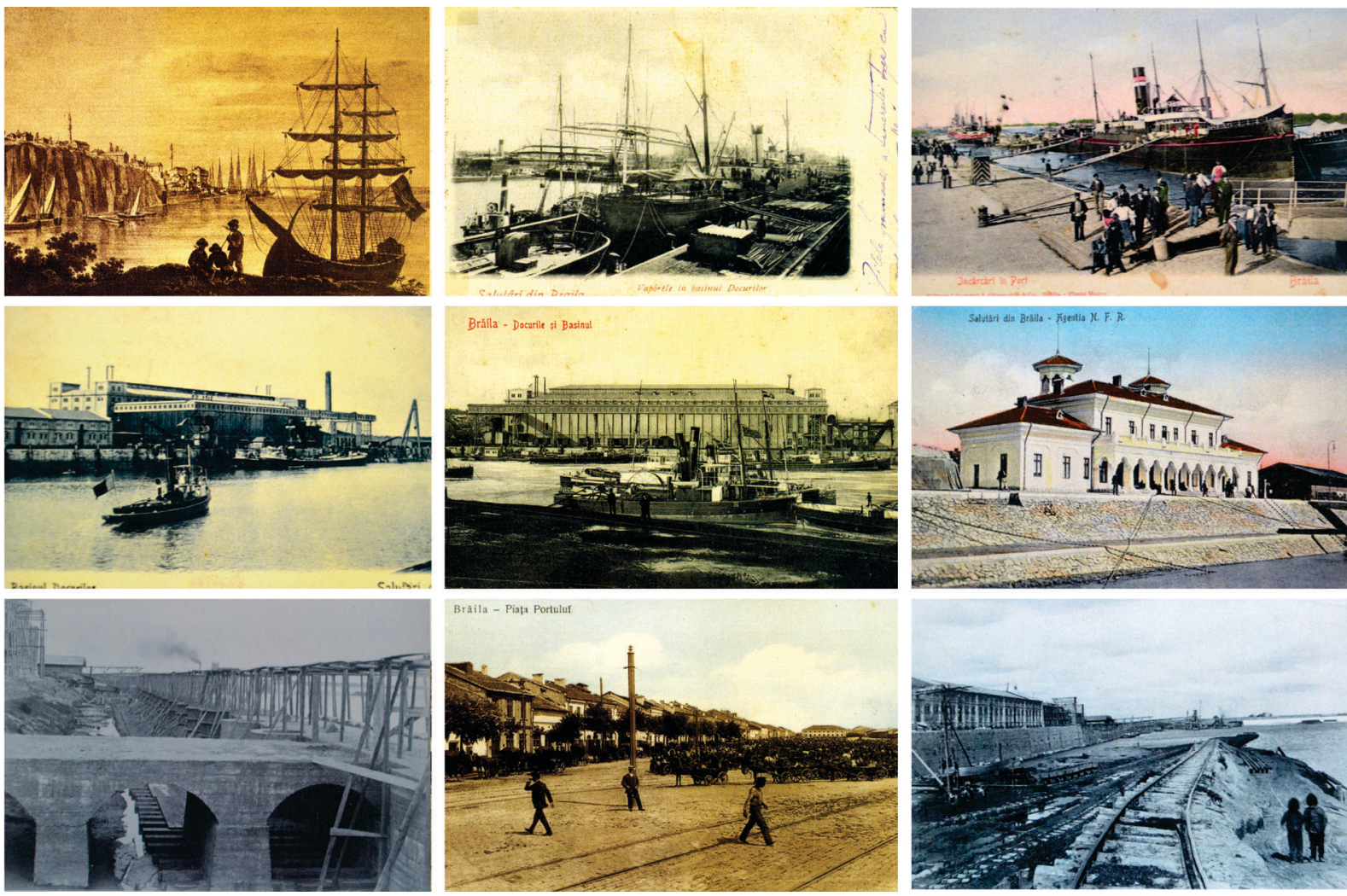

Vistas do porto em diferentes épocas

O património urbano de Braila é composto essencialmente pela sua estrutura urbana, que ficou traçada no século XIX. A estrutura carateriza-se por uma regularidade e uma ordem que não se tornam monótonas, integrando, de uma forma articulada, a velha estrutura não intervencionada. O formato semicircular das ruas oitocentistas, com ampla abertura lateral na direção do rio e com as artérias em disposição radial e relativamente equidistantes entre si, fazem de Braila uma cidade singular no contexto romeno. Contudo, 
também o património edificado é significativo e valioso, contando com edifícios públicos e prédios residenciais de tipologia variada e expressão arquitetónica diversa, que refletem, na sua grande parte, o estilo eclético da época em que foram construídos. Caraterística assinalável, e simultaneamente prova do multiculturalismo de Braila, é o elevado número de igrejas de diferentes credos, como sejam a Igreja Grega (a mais imponente de todas), a Igreja Católica, a Igreja Ortodoxa e a Igreja Lipovana. Uma parte significativa do património edificado está associada às atividades industriais e portuárias que têm lugar na cidade.

Entre os edifícios a referir, os casos mais notórios são as fábricas Violatos (1898) e Lichiardopulos (1910-1912), situadas junto ao rio, que também constituem pontos fortes desta parte da cidade. Igualmente importantes são os silos, concebidos por Anghel Saligny no final da década de 1880. Para além destes, um vasto conjunto de construções e edifícios com as mais diversas funções - oficinas, fábricas, armazéns, depósitos, ou o edificio da administração do porto - acrescenta valor ao património edificado. A presença deste património levou à classificação do conjunto do centro urbano, incluindo o porto, como "centro histórico". Em suma, todos estes aspetos contribuem para o reafirmar da identidade cultural de Braila.

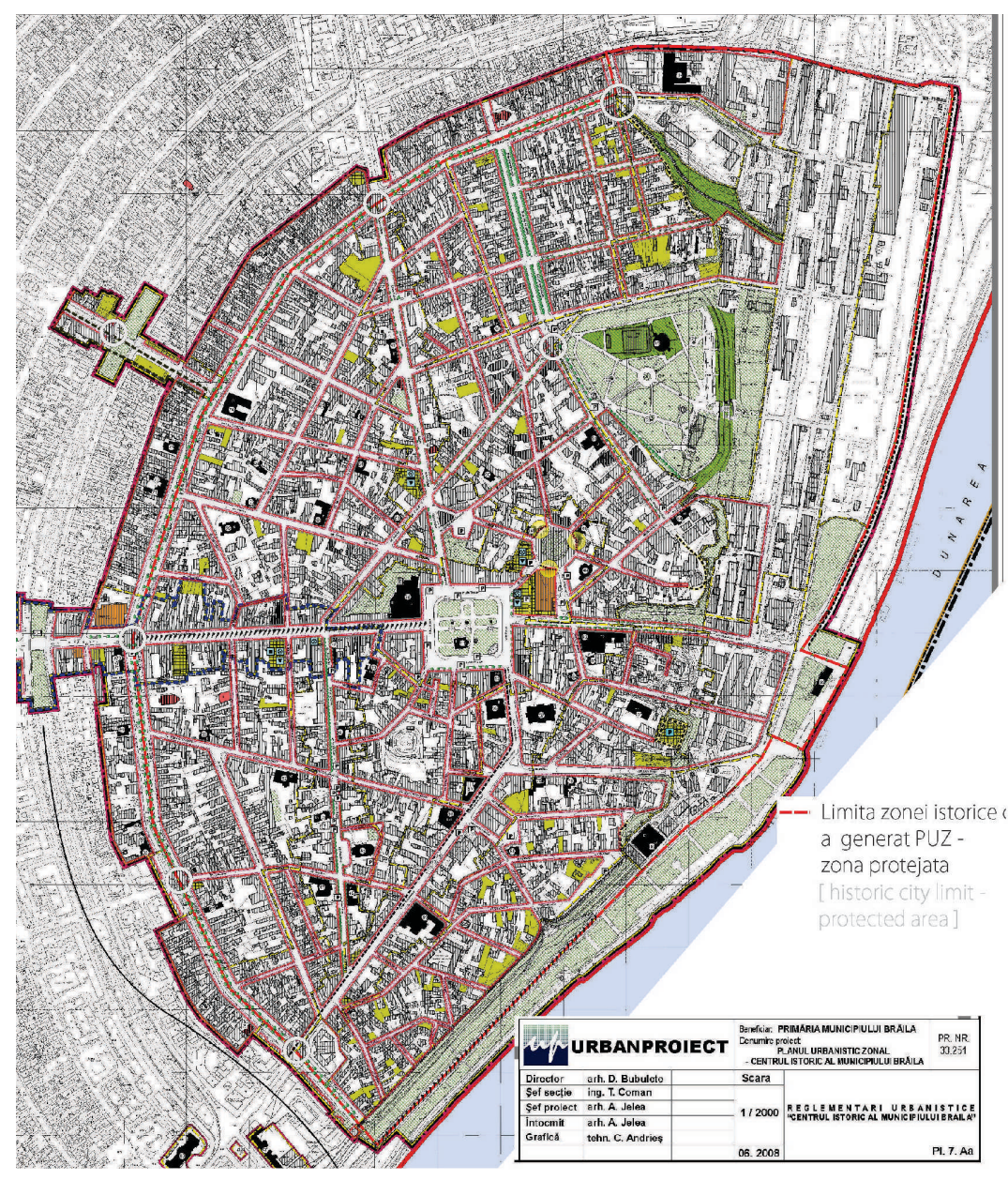

Plano da área protegida - 2008 / Limites da cidade histórica 

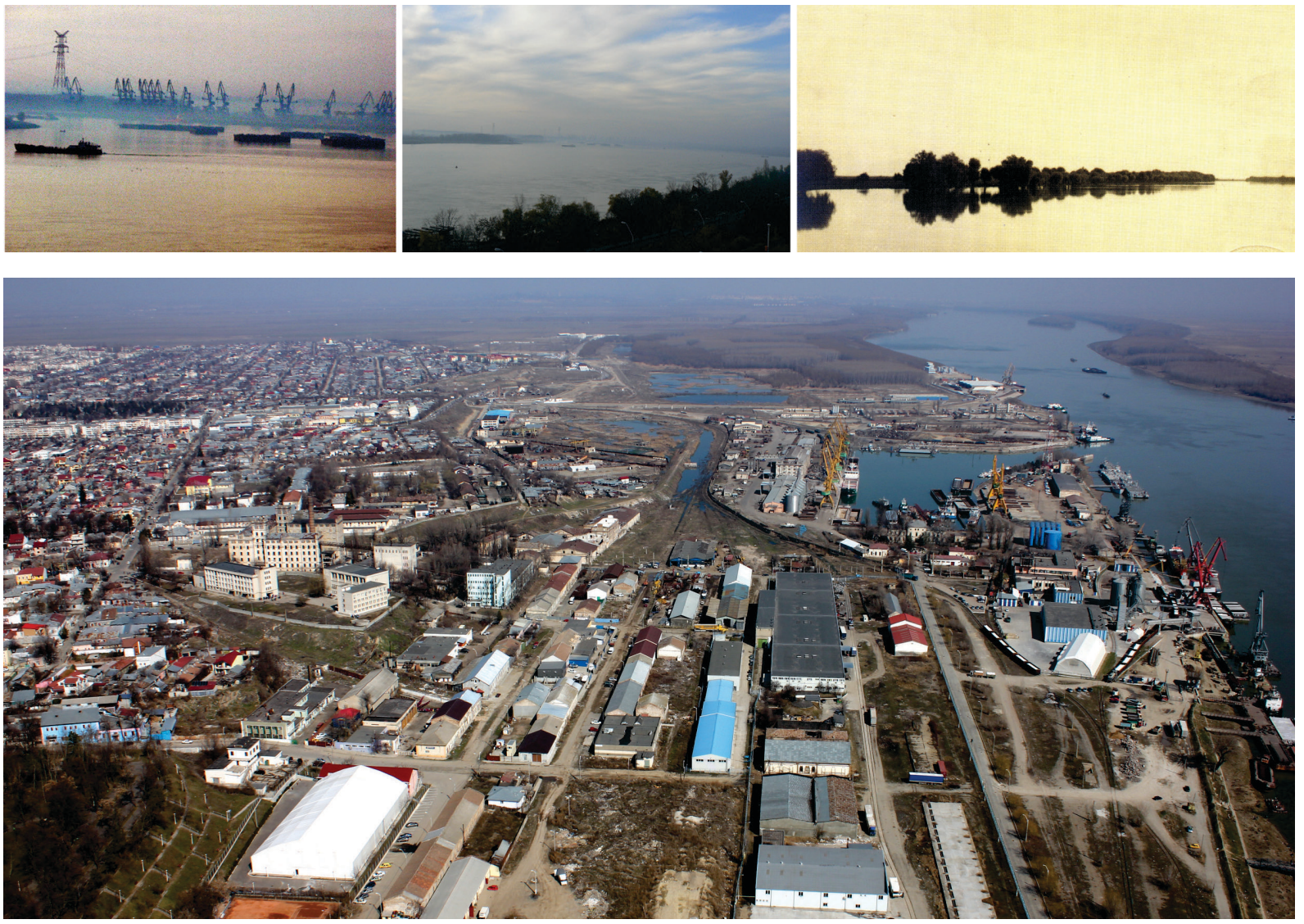

Vista aérea do porto - 2012

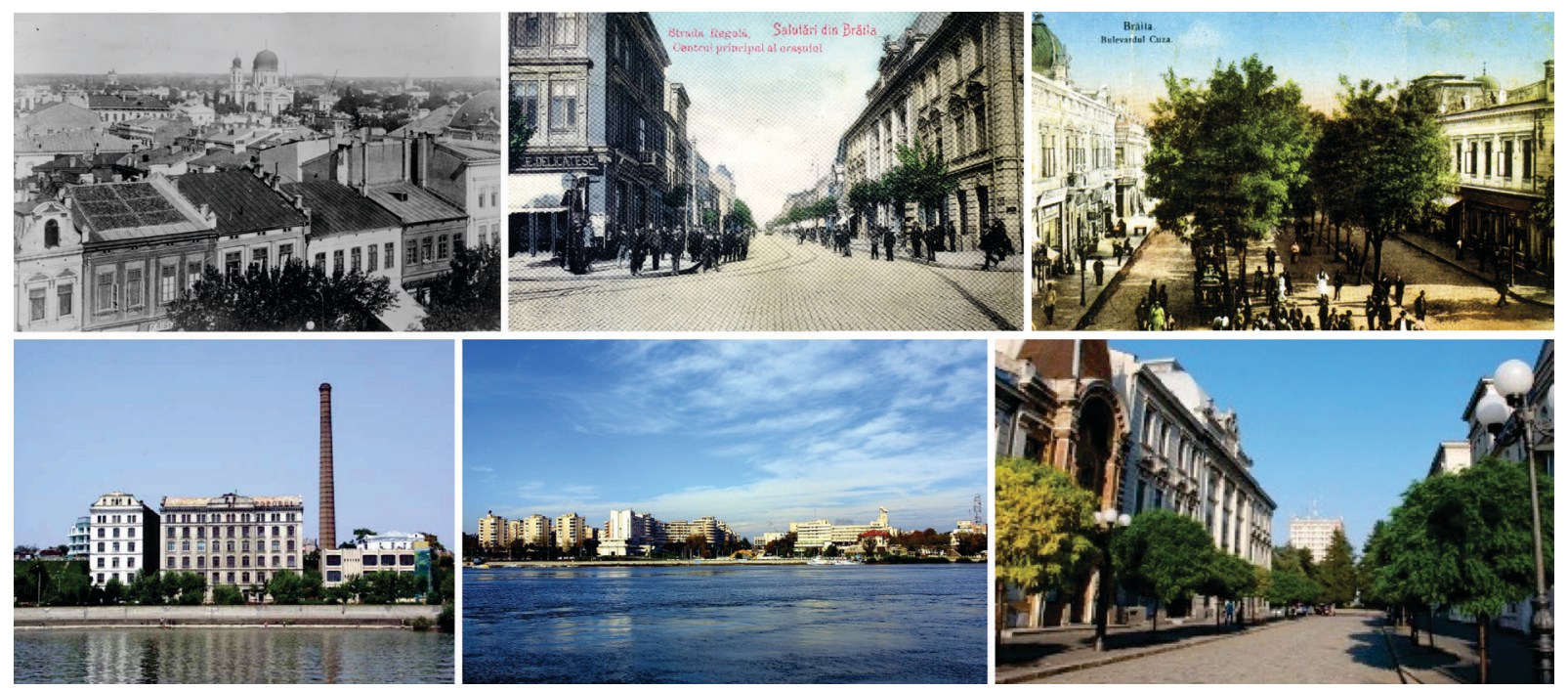

Fotografias diversas da cidade e do rio 


\section{Diagnóstico}

Situada na unidade de paisagem do Baixo Danúbio, Braila é uma componente crucial do futuro sistema urbano de Braila-Galati. A singularidade da sua história ditou-Ihe algumas das caraterísticas no que concerne à relação com a água e com toda a frente ribeirinha. Em primeiro lugar, a configuração geral da cidade - em forma de semicírculo, de que é exemplo único na Roménia, abrindo-se para o Danúbio e acentuando, assim, o papel do rio como limite natural, já que a cidade se desenvolveu apenas na margem esquerda. Em segundo lugar, a localização em dois socalcos e portanto em altitudes diferentes, facto que, se por um lado proporciona, a partir do bordo do socalco superior, amplas vistas sobre o Danúbio e o Paúl de Braila, por outro lado coloca alguns inconvenientes no que se refere à ligação das duas partes da cidade. Em terceiro lugar o uso prolongado do socalco inferior para as atividades do porto e com este relacionadas, incluindo o transporte de pessoas, e também a conceção e apetrechamento, na segunda metade do século passado, de uma extensão linear de passeio localizada na parte sul do centro histórico.

Ao longo dos últimos 20 anos a zona portuária foi afetada por drásticas mudanças. A redução da atividade económica, a reestruturação ou desaparecimento, na zona do porto, de algumas unidades industriais e comerciais, e também a crise económica, conduziram ao abandono de grandes superfícies edificadas - salões, armazéns, etc., algumas delas com uma arquitetura de qualidade, mas que presentemente se encontram num estado de colapso físico - ou, noutros casos, à demolição dos prédios industriais e à sua substituição por edificações de natureza provisória. A alguns terrenos, de dimensão variável, foi concedido o estatuto especial de "zona liberta". Em resultado destas mudanças, a área edificada compacta que existia no século passado, e que é possível ver nas fotografias antigas, acha-se hoje numa situação de desestruturação avançada. Toda esta área está situada na parte norte do centro histórico, onde o socalco inferior se abre como que em leque.

A topografia do terreno, a redução e alteração das atividades portuárias, a qualidade do património industrial, e a multiplicidade de hipóteses para que se desenvolvam, na densidade do território urbano, laços orgânicos entre a cidade e a frente ribeirinha, são fatores que, conjuntamente, apontam para um potencial particularmente complexo, no sentido da reapropriação do elemento água. Para concretizar tal reapropriação deverá promover-se: o prolongamento, até à área das docas, da área de passeio existente (a Promenada); o acentuado reforço da Rua de Trajano como eixo desta área de passeio; o prolongamento - com o respetivo tratamento paisagístico - do jardim público até ao socalco inferior; a reconstrução das estruturas lineares outrora edificadas para fins de armazenamento e atividades portuárias em geral; o prolongamento das instalações da fábrica Lichiardopulos relacionadas com a água, com vista a funcionarem como infraestrutura pública, numa ligação da cidade à frente ribeirinha; e a ligação da cidade à outra margem do Danúbio. 

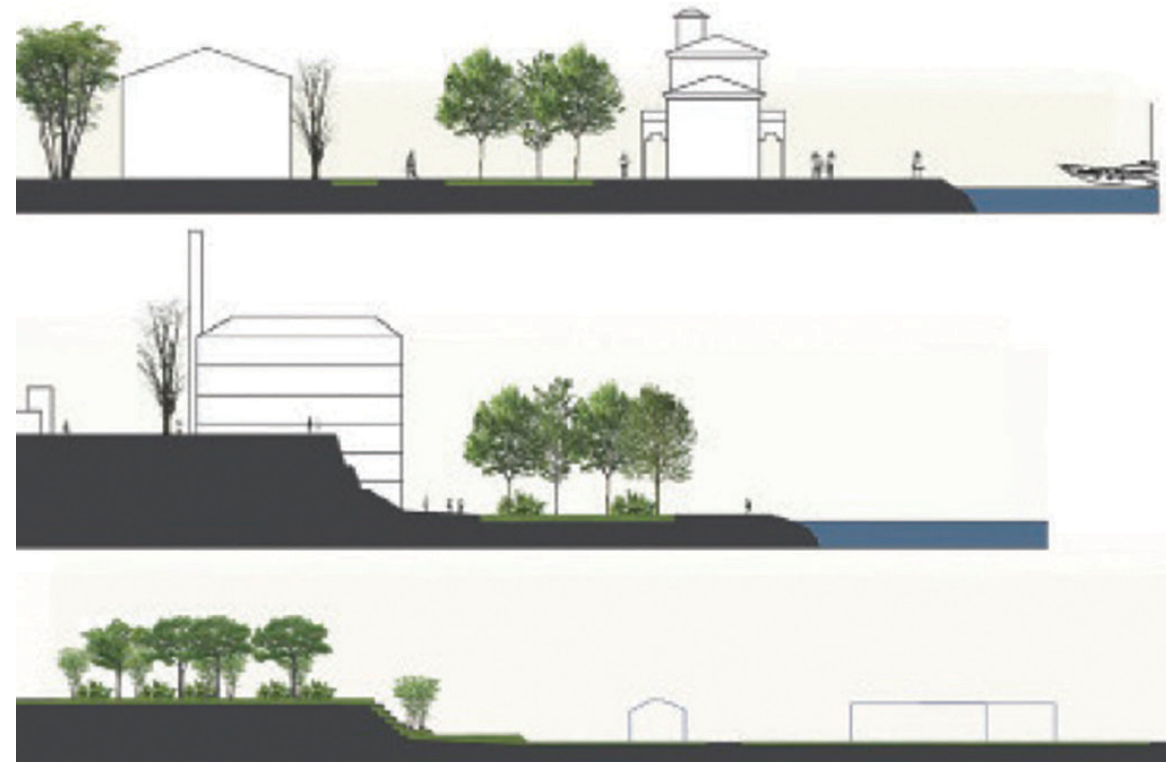

Perfis do terreno correspondentes à situação existente na zona do porto

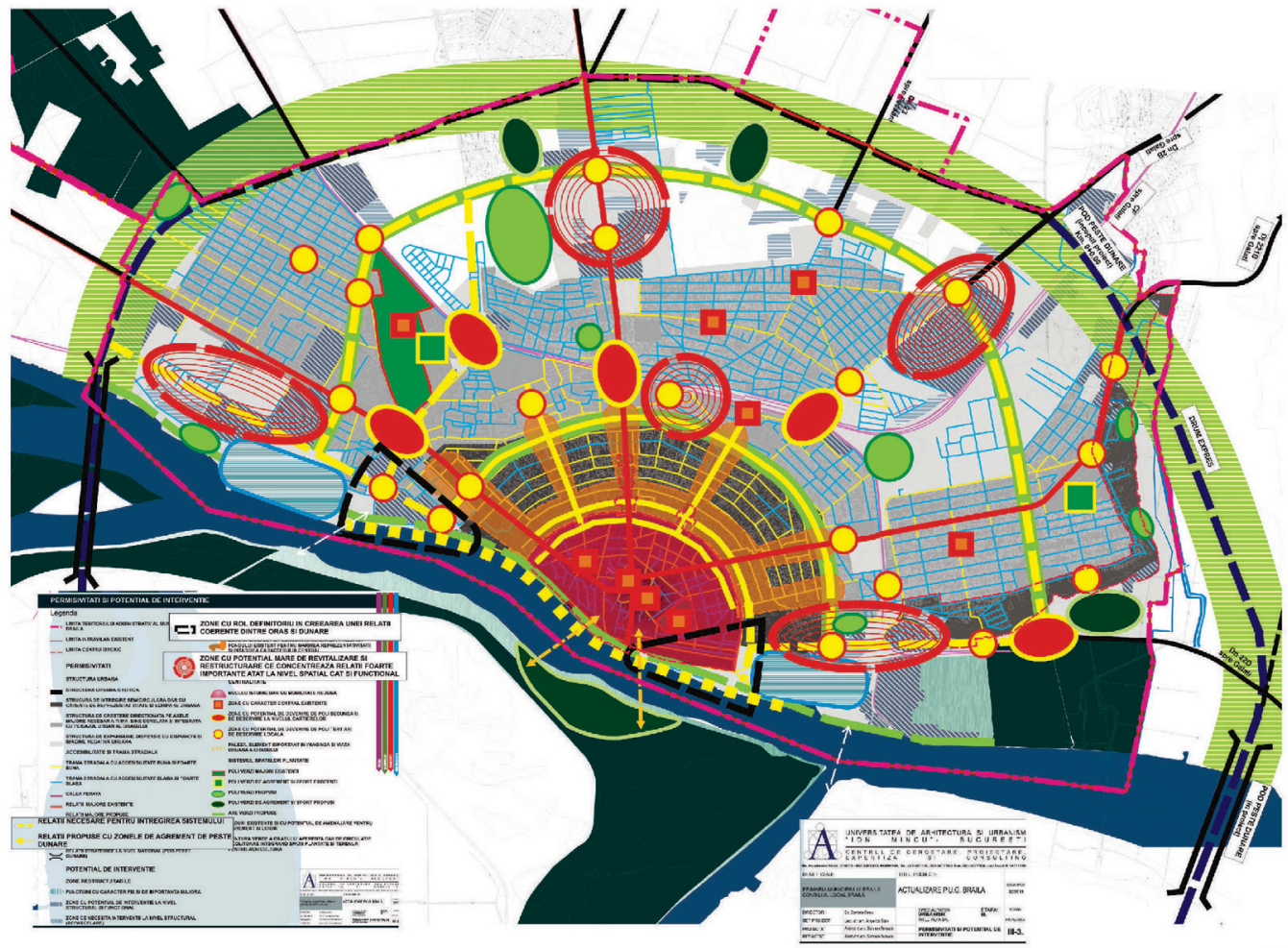

Plano diretor genérico (projeto em curso) - área com potencial de desenvolvimento 